\title{
The effect of continuous positive airway pressure on nocturia in patients with obstructive sleep apnea syndrome
}

Citation for published version (APA):

Vrooman, O. P. J., van Balken, M. R., van Koeveringe, G. A., van Kerrebroeck, P. V. A., Driessen, L. E. M. J., Schouten, L. J., \& Rahnama'i, M. S. (2020). The effect of continuous positive airway pressure on nocturia in patients with obstructive sleep apnea syndrome. Neurourology and Urodynamics, 39(4), 11241128. https://doi.org/10.1002/nau.24329

Document status and date:

Published: 01/04/2020

DOI:

10.1002/nau.24329

Document Version:

Publisher's PDF, also known as Version of record

Document license:

Taverne

Please check the document version of this publication:

- A submitted manuscript is the version of the article upon submission and before peer-review. There can be important differences between the submitted version and the official published version of record.

People interested in the research are advised to contact the author for the final version of the publication, or visit the DOI to the publisher's website.

- The final author version and the galley proof are versions of the publication after peer review.

- The final published version features the final layout of the paper including the volume, issue and page numbers.

Link to publication

\footnotetext{
General rights rights.

- You may freely distribute the URL identifying the publication in the public portal. please follow below link for the End User Agreement:

www.umlib.nl/taverne-license

Take down policy

If you believe that this document breaches copyright please contact us at:

repository@maastrichtuniversity.nl

providing details and we will investigate your claim.
}

Copyright and moral rights for the publications made accessible in the public portal are retained by the authors and/or other copyright owners and it is a condition of accessing publications that users recognise and abide by the legal requirements associated with these

- Users may download and print one copy of any publication from the public portal for the purpose of private study or research.

- You may not further distribute the material or use it for any profit-making activity or commercial gain

If the publication is distributed under the terms of Article $25 \mathrm{fa}$ of the Dutch Copyright Act, indicated by the "Taverne" license above, 


\title{
The effect of continuous positive airway pressure on nocturia in patients with obstructive sleep apnea syndrome
}

\author{
Olaf P. J. Vrooman MD ${ }^{1}$ (i) | Michael R. van Balken MD, PhD $^{\mathbf{1}}$ | \\ Gommert A. van Koeveringe MD, PhD $^{2} \quad$ Philip V. A. van Kerrebroeck MD, PhD $^{2}$ | \\ Lizzy E. M. J. Driessen PhD $^{3}$ | Leo J. Schouten PhD $^{3}$ | \\ Mohammad S. Rahnama'i MD, $\mathbf{P h D}^{2}$
}

${ }^{1}$ Department of Urology, Hospital Rijnstate Arnhem, Arnhem,

The Netherlands

${ }^{2}$ Department of Urology, University Hospital Maastricht, Maastricht,

The Netherlands

${ }^{3}$ Department of Epidemiology, Maastricht University, Maastricht, Limburg,

The Netherlands

\section{Correspondence}

Olaf P. J. Vrooman, MD, Department of

Urology, Hospital Rijnstate Arnhem,

PO box 9555, 6800 TA Arnhem,

The Netherlands.

Email: o.vrooman@gmail.com

\begin{abstract}
Objective: The prevalence of nocturia in patients with obstructive sleep apnea syndrome (OSAS) who received continuous positive airways pressure (CPAP) treatment was studied as well as the effect of CPAP treatment on nocturia. Methods: All patients that were referred to the pulmonology department of a large teaching hospital in the Netherlands and received a CPAP mask for OSAS were interviewed and invited to take part in the study $(\mathrm{N}=274)$. After informed consent, all patients were asked about the number of nocturia episodes before and after CPAP.

Results: In this prospective analysis, 274 patients (190 male and 84 female) were included. The mean age was 60.3 years $(\mathrm{SE}=0.7)$. Sixty-four patients (23.4\%) reported no nocturia episodes before CPAP and 210 patients (76.4\%) reported $\geq 1$ nocturia episode(s). Treatment of OSAS with CPAP reduced nocturia with one or more episodes per night in $42.3 \%$ of the patients. Clinically relevant nocturia ( $\geq 2$ voids per night) was reduced from $73.0 \%$ to $51.5 \%$. There were no statistically significant gender differences.

Conclusion: The prevalence of nocturia in patients diagnosed with OSAS is $75.8 \%$ in both sexes. After treatment with CPAP, almost half of patients experienced a decrease in the nocturia frequency of one or more voids. Clinically relevant nocturia was reduced with one-third after CPAP. CPAP not only reduced the number of voids during the night but also improved the associated quality of life.

K E Y W O R D S

CPAP, nocturia, OSAS
\end{abstract}

\section{1 | INTRODUCTION}

Obstructive sleep apnea syndrome (OSAS) is a chronic sleep disorder characterized by recurrent episodes of obstruction of the upper airway causing intermittent hypoxemia and hypercapnia and sleep fragmentation. ${ }^{1}$ These adverse effects of
OSAS are important mediators of metabolic, cardiovascular, and neurocognitive risk. ${ }^{2}$ Because of the nonspecific symptoms, OSAS often remains undiagnosed.

Several studies suggest that nocturia may be related to OSAS. ${ }^{3-5}$ Oztura et $\mathrm{al}^{6}$ found that OSAS was significantly associated with nocturnal urination in 1970 patients with 
OSAS. In patients with OSAS, nighttime frequency of more than once is reported to be $52 \%$ to $77 \%$, depending on the severity of sleep-disordered breathing. ${ }^{6,7}$

The mechanisms by which OSAS induces nocturia have not been elucidated and a few mechanisms have been suggested to be involved in the pathophysiology. One mechanism is that disruption of sleep may lead to a decision to void. Pressman et $\mathrm{al}^{8}$ showed that most awakenings from sleep attributing feeling the urge to urinate were a result of sleep disorders, particularly OSAS. But this theory does not explain the nocturnal polyuria. Another mechanism by which OSAS develops nocturia and nocturnal polyuria is thought to be the existence of an increasingly negative intrathoracic pressure caused by partial or complete occlusion of the airway. Each diaphragmatic contraction against obstruction results in a corresponding pulse of negative thoracic pressure and positive abdominal pressure. This stimulates venous return to the atrium and gives a false fluid overload signal. Together with the also developing hypoxemia this results in an increased atrial natriuretic peptide (ANP) secretion. ${ }^{9}$ ANP acts on the kidney to increase sodium and water excretion (natriuresis) and leads to the nighttime polyuria responsible for the nocturia. Furthermore, there are age-related changes in sleep depth and continuity and age-related changes in circadian rhythm amplitude that may contribute to nocturia. ${ }^{10}$

One treatment of OSAS is continuous positive airway pressure (CPAP) and thereby it is possible that it can reduce nocturia in these patients provided that no other physiological cause contributed to nocturia. CPAP is effective in reducing symptoms of sleepiness and improving quality of life (QoL) measures in people with moderate and severe OSAS. ${ }^{11}$

In lower urinary tract symptoms (LUTS), consisting of voiding, postvoiding, and storage symptoms (including nocturia), nocturia is consistently reported to be one of the most bothersome symptoms by male as well as female. ${ }^{12}$

Despite the bother experienced by patients, nocturia is an underreported condition and therefore, the true extent of the problem in the population may be underestimated. As nocturia is underreported, the true incidence of nocturia in the population and more specifically in patients suffering from OSAS is likely to be higher.

The primary aim of this study was to assess the prevalence of nocturia in patients with OSAS who received CPAP. Furthermore, sex differences and QoL were investigated as well.

\section{2 | METHODS}

All patients who were referred to the pulmonology department of a large teaching hospital in the Netherlands and received a CPAP mask for OSAS during 1 year (20142015) $(\mathrm{N}=368)$ were invited for a telephone interview regarding nocturia and QoL related to micturition. All patients were interviewed about their nocturia episodes prior to and after CPAP. The interviews were conducted in 2016 cross-sectionally after informed consent was provided. Interviewees underwent at least 1 year of CPAP treatment. Study data were gained from the interview as well as medical records. Following the nature of this study and the rules of the Dutch Central Committee on Research involving Human Subjects (CCMO), central approval of an ethics committee was not required to conduct the study. Local approval was gained by the hospital board.

OSAS was defined as a breathing disorder in which a person frequently stops breathing during his or her sleep and results from an obstruction of the upper airway that occurs because of the inadequate motor tone of the tongue and/or airway dilator muscles. Nocturia has been defined by the International Continence Society as "the need to void one or more times during the night, with each void preceded and followed by sleep." 13 A more clinically relevant definition of nocturia is " $\geq 2$ voids per night" as at this point it would become bothersome for most individuals. ${ }^{14,15}$ In descriptive analysis, the following information was taken into account: baseline characteristics (age, sex, concomitant diseases, medication use, medical history, and use of CPAP), nocturia (number of nocturnal voids before CPAP, number of nocturnal voids after CPAP, difference in number of nocturnal voids before and after CPAP), and QoL regarding micturition (QoL before CPAP [good-fairpoor], QoL after CPAP [good-fair-poor], difference in QoL before and after CPAP).

Statistical analysis was performed using IBM SPSS statistics 23.0. Continuous data were presented as mean $( \pm \mathrm{SE})$ or median (interquartile range [IQR]). Categorical data were presented as numbers (percentages). Statistical differences were assessed by the Student $t$ test for continuous outcomes and by $\chi^{2}$ tests for categorical outcomes. In case the number of expected patients was too low to conduct the $\chi^{2}$ test, the likelihood ratio was used. A $P<.05$ was deemed as a statistically significant difference.

\section{3 | RESULTS}

Of the 368 patients who were called, 285 patients, (198 male and 87 female) were reached and gave consent to take part in our study. We obtained the requested data from 274 people (190 male and 84 female). The mean age of the interviewed population at that time was 60.3 years $(\mathrm{SE}=0.7)$. Analyzing the different age groups, there are statistically significant $(P=.011)$ more men with OSAS in 


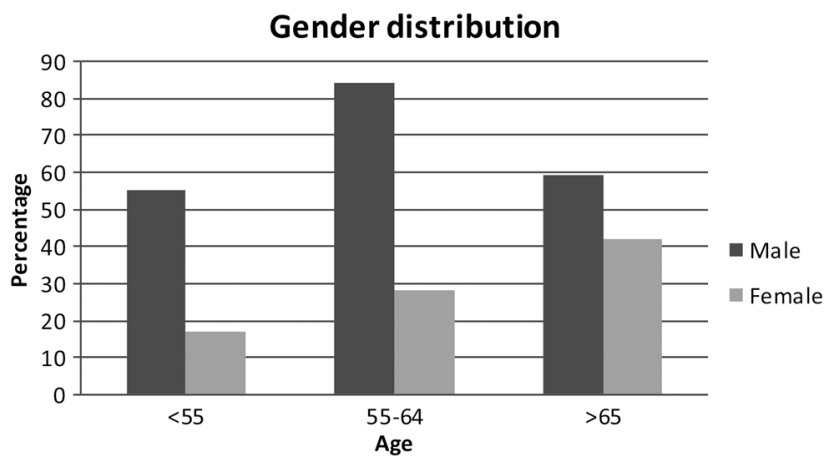

FIG URE 1 Gender distribution of OSAS by age

each group; see Figure 1. Furthermore, there is a peak incidence of OSAS in male between 55 to 64 years old. In the female the increase is gradual as the age increases. There was not a statistically significant difference with respect to the prevalence of nocturia between the sexes prior $(P=.936)$ or after CPAP treatment $(P=.398)$; see Table 1. Furthermore, no difference was observed with regard to QoL before and after CPAP treatment (with respectively $P=.257$ and $P=.664$ ).

In the interviewed population $42 \%$ experienced some LUTS prior to CPAP treatment. An overview of these

TABLE 1 Gender differences in nocturia and related QoL

\begin{tabular}{|c|c|c|c|c|}
\hline $\begin{array}{l}\text { Nocturia frequency } \\
\text { before CPAP }\end{array}$ & Ma & le $\%$ & Female & $\%$ \\
\hline $0-1$ & 51 & 26.3 & 23 & 26.7 \\
\hline$\geq 2$ & 143 & 73.7 & 63 & 73.3 \\
\hline Total & 194 & 100 & 86 & 100 \\
\hline $\begin{array}{l}\text { Nocturia frequency } \\
\text { after CPAP }\end{array}$ & Ma & le $\%$ & Female & $\%$ \\
\hline $0-1$ & 89 & 46.8 & 44 & 52.4 \\
\hline$\geq 2$ & 101 & 53.2 & 40 & 47.6 \\
\hline Total & 190 & 100 & 84 & 100 \\
\hline Rating QoL before CPAP & Male & $\%$ & Female & $\%$ \\
\hline Good & 128 & 72.3 & 53 & 67.1 \\
\hline Fair & 30 & 16.9 & 20 & 25.3 \\
\hline $\mathrm{Bad}$ & 19 & 10.7 & 6 & 7.6 \\
\hline Total & 177 & 100 & 79 & 100 \\
\hline Rating QoL after CPAP & Male & $\%$ & Female & $\%$ \\
\hline Good & 160 & 90.4 & 67 & 87 \\
\hline Fair & 16 & 9 & 9 & 11.7 \\
\hline $\mathrm{Bad}$ & 1 & 0.6 & 1 & 1.3 \\
\hline Total & 177 & 100 & 77 & 100 \\
\hline
\end{tabular}

Abbreviations: CPAP, continuous positive airways pressure; QoL, quality of life.
LUTS is summarized in Table 1 . In Table 2 micturitionrelated medication is shown before and after CPAP treatment. Few differences in medication use were seen before and after treatment with CPAP (Table 3).

Sixty-four patients (23.4\%) reported to have had no nocturia episodes before CPAP, 210 patients $(76.6 \%)$ reported one or more nocturia episode(s). The distribution of the nocturia frequency is shown in Table 4. It is obvious that after starting with CPAP the nocturia frequency has decreased over the entire range. Excesses, in particular, have been reduced and the nocturia frequency has been reduced to a maximum of 4 times instead of 7. Overall $116(42.3 \%)$ patients have experienced a decrease in voids. Furthermore, $200(73.0 \%)$ patients had a clinically relevant ( $\geq 2$ voids per night) nocturia. The median nocturia frequency before CPAP was $3(\mathrm{IQR}=3)$. After treatment with CPAP, the number of patients with clinically relevant nocturia was 141 (51.5\%). The median nocturia frequency after CPAP was $2(\mathrm{IQR}=2)$. The mean reduction of nocturia after starting treatment with CPAP was -1.09 with a standard deviation of 1.58 $(P$-value one-sample $t$ test: <.001).

Analyzing the effects of the treatment on the QoL regarding micturition, we noticed a statistically significant $(P<.001)$ improvement of the QoL after the treatment; see Table 4.

Two hundred seventy patients were asked whether medical help was sought for nocturia. This was only the case with 36 people (13.3\%). In 193 interviewees, it was possible to find out the reason for not seeking medical help for this complaint. By far the largest group, 109 interviewees (56.5\%) experienced no complaints, 42 patients (21.8\%) did not experience the nocturia as annoying and 15 patients $(7.8 \%)$ were assuming that it is normal to void at night. The remaining group indicated a wide range of reasons for not requesting medical assistance.

\section{4 | DISCUSSION}

The results of this study show that more than threequarters of patients with OSAS suffer from nocturia. In our study, it was noticeable that few patients seek medical help for this problem. Many of those interviewed did not see it as a complaint or assumed it was normal. A study by Oelke et $\mathrm{al}^{16}$ recently found that nocturia is an underreported, undertreated, and poorly managed medical and social problem in adults. In this study, it was found that the total time from the first symptom appearance to first prescribed treatment was approximately 2 years. This suggests that physicians may underestimate the symptom burden and decreased QoL associated with nocturia. Our results indicate that also patient awareness is necessary in recognizing nocturia as a problem. In 
TABLE 2 LUTS before CPAP treatment

\begin{tabular}{|llcc|}
\hline LUTS specification & Frequency & \% & Valid \% \\
\hline Nocturia & 31 & 10.9 & 29.2 \\
\hline LUTS not specified & 28 & 9.9 & 26.4 \\
\hline LUTS for which TURP & 15 & 5.3 & 14.2 \\
\hline Urge & 11 & 3.9 & 10.4 \\
\hline Nighttime incontinence & 10 & 3.5 & 9.4 \\
\hline Incontinence not specified & 7 & 2.6 & 6.5 \\
\hline Chronic residue & 3 & 1.1 & 2.8 \\
\hline Stress urinary incontinence & 1 & 0.4 & 0.9 \\
\hline & 106 & 37.2 & 100 \\
\hline
\end{tabular}

Abbreviations: CPAP, continuous positive airways pressure; LUTS, lower urinary tract symptoms; TURP, transurethral resection of the prostate.

addition, nocturia has been identified as an independent predictor for severe OSAS. ${ }^{17,18}$ Yamamoto et $\mathrm{al}^{19}$ looked at the prevalence of OSAS among patients that visited a urology clinic complaining of nocturia. They reported that OSAS is as prevalent in patients who visit a urology clinic complaining of nocturia as in those who visit a sleep apnea clinic. Of the 34 patients who also had consulted a urologist, $70 \%$ had more than mild OSAS. Because many patients seek help for nocturia instead of OSAS further study of patient characteristics is necessary to identify the patients with OSAS in particular because the cause of nocturia is multifactorial.

In this study, $42.3 \%$ of all patients treated with CPAP, experienced a reduction of nocturia with one or more voiding episodes per night. Although the limitation of this study is its retrospective nature it shows significant improvement of nocturia and QoL. In this study, we used

TABLE 3 Use of medication before and after treatment

\begin{tabular}{|lllll|}
\hline Medication & $\begin{array}{l}\text { Frequency } \\
\text { pre CPAP }\end{array}$ & $\%$ & $\begin{array}{l}\text { Frequency } \\
\text { after CPAP }\end{array}$ & $\%$ \\
\hline $\begin{array}{c}\text { No urinary- } \\
\quad \begin{array}{l}\text { related } \\
\text { medication }\end{array}\end{array}$ & 203 & 71.2 & 215 & 75.4 \\
\hline $\begin{array}{l}\text { Not clear } \\
\text { Urinary-related }\end{array}$ & 19 & 7.7 & 10 & 3.5 \\
\hline $\begin{array}{l}\text { medication } \\
\text { Mirabegron }\end{array}$ & 1 & 6.7 & 16 & 5.6 \\
\hline Anticholinergic & 4 & 0.4 & 4 & 1.4 \\
\hline Diuretics & 17 & 1.5 & 4 & 1.5 \\
\hline Alfa blocker & 1 & 2.5 & 16 & 5.6 \\
\hline & 267 & 0.4 & 1 & 0.4 \\
\hline
\end{tabular}

Abbreviation: CPAP, continuous positive airways pressure.
TA B LE 4 Reduction of clinically significant nocturia and effect of CPAP on QoL regarding micturition

\begin{tabular}{|lllll}
$\begin{array}{l}\text { Nocturia } \\
\text { frequency }\end{array}$ & Before CPAP & $\%$ & After CPAP & $\%$ \\
\hline $0-1$ & 74 & 26 & 133 & 48.5 \\
\hline 2 & 206 & 72.3 & 141 & 51.5 \\
\hline Total & 280 & & 274 & \\
\hline Missing & 5 & & 11 & \\
\hline Rating QoL & Before CPAP & $\%$ & After CPAP & $\%$ \\
\hline Good & 181 & 70.7 & 227 & 89.4 \\
\hline Fair & 50 & 19.5 & 25 & 9.8 \\
\hline Bad & 25 & 9.8 & 2 & 0.8 \\
\hline Total & 256 & 100 & 254 & 100 \\
\hline Missing & 29 & & 31 & \\
\hline
\end{tabular}

Abbreviations: CPAP, continuous positive airways pressure; QoL, quality of life.

the definition of bothersome nocturia (" $\geq 2$ voids per night") which is at least arbitrary. The first interrupted sleep period may be more useful in future analysis to measure the effect on sleep quality. ${ }^{20}$

CPAP is effective in reducing symptoms of sleepiness and improving QoL measures in people with moderate and severe OSAS. ${ }^{11}$ CPAP also seems to be effective in reducing the frequency of nocturia and the associated nighttime polyuria. ${ }^{21}$ In a meta-analysis by Wang et al, ${ }^{22}$ it was concluded that CPAP possibly is an effective treatment for reducing nocturia associated with OSAS and improves the QoL in these patients. At this time CPAP is not the only treatment option in OSAS and the effect of other treatment options like lifestyle changes, oral devices, and surgical procedures must also be evaluated.

We did see that the prevalence of OSAS in men is more concentrated in the age category between 55 and 65 years while in women the increase is gradual as they age. A possible explanation lies in the relationship between lifestyle factors and OSAS. In women, it appears to be mainly caused by aging. The clinical consequence could be that clinicians are more alert in diagnosing OSAS in a middle-aged man when nocturia is the main complaint. Furthermore, studies on lifestyle interventions may give rise to better treatment options in patients with nocturia caused by OSAS.

\section{5 | CONCLUSION}

The prevalence of nocturia in patients diagnosed with OSAS is $75.8 \%$ in both males and females. There were no statistically significant sex differences. Although arbitrary, a nocturia frequency of 2 or more is found to be bothersome 
and is therefore called clinically relevant, and is prevalent in almost three-quarters of all patients. This study also provides an indication for more research into recognizing the nocturia as a symptom by patients so that help is sought more and more quickly. After treatment with CPAP, almost half of the patients experienced a decrease in the nocturia frequency of one or more voids. Clinically relevant nocturia was reduced with one-third after CPAP. CPAP not only reduced the number of voids during the night but also improved the associated QoL. Almost no one scored bad after treatment.

This study shows that there is a relation between nocturia and OSAS and this should prompt the urologist to think outside of the "urology box." The multifactorial nature of Nocturia deserves often a multidisciplinary approach and in the case of OSAS referral to a pulmonologist and treatment of these patients with CPAP can relieve symptoms in almost half of patients and treatment with CPAP shows a clear improvement in the QoL.

\section{ORCID}

Olaf P. J. Vrooman (D) http://orcid.org/0000-0002-

9279-2847

Mohammad S. Rahnama'I (D) http://orcid.org/0000-00031953-7441

\section{REFERENCES}

1. Reutrakul S, Mokhlesi B. Obstructive sleep apnea and diabetes: a state of the art review. Chest. 2017;152(5):1070-1086.

2. Heinzer R, Vat S, Marques-Vidal P, et al. Prevalence of sleepdisordered breathing in the general population: the HypnoLaus study. Lancet Respir Med. 2015;3(4):310-318.

3. Guilleminault C, Abad VC. Obstructive sleep apnea syndromes. Med Clin North Am. 2004;88(3):611-630.

4. Yan AT, Bradley TD, Liu PP. The role of continuous positive airway pressure in the treatment of congestive heart failure. Chest. 2001;120(5):1675-1685.

5. Jennum P. Sleep and nocturia. BJU Int. 2002;90(suppl 3):21-24.

6. Oztura I, Kaynak D, Kaynak HC. Nocturia in sleep-disordered breathing. Sleep Med. 2006;7(4):362-367.

7. Kaynak H, Kaynak D, Oztura I. Does frequency of nocturnal urination reflect the severity of sleep-disordered breathing? J Sleep Res. 2004;13(2):173-176.

8. Pressman MR. Nocturia. A rarely recognized symptom of sleep apnea and other occult sleep disorders. Arch Intern Med. 1996; 156(5):545-550.

9. Umlauf MG, Chasens ER, Greevy RA, Arnold J, Burgio KL, Pillion DJ. Obstructive sleep apnea, nocturia and polyuria in older adults. Sleep. 2004;27(1):139-144.

10. Duffy JF, Scheuermaier K, Loughlin KR. Age-related sleep disruption and reduction in the circadian rhythm of urine output: contribution to nocturia? Curr Aging Sci. 2016;9(1): 34-43.

11. Giles T, Lasserson T, Smith B, White J, Wright J, Cates C. Continuous positive airways pressure for obstructive sleep apnoea in adults. Cochrane Database Syst Rev. 2006;25(1). CD001106.

12. Bosch JL, Weiss JP. The prevalence and causes of nocturia. J Urol. 2013;189(suppl 1):S86-S92.

13. van Kerrebroeck P, Abrams P, Chaikin D, et al. The standardisation of terminology in nocturia: report from the Standardisation Sub-committee of the International Continence Society. Neurourol Urodyn. 2002;21(2):179-183.

14. Chen FY, Dai YT, Liu CK, Yu HJ, Liu CY, Chen THH. Perception of nocturia and medical consulting behavior among community-dwelling women. Int Urogynecol J Pelvic Floor Dysfunct. 2007;18(4):431-436.

15. Tikkinen KAO, Johnson TM, Tammela TLJ, et al. Nocturia frequency, bother, and quality of life: how often is too often? A population-based study in Finland. Eur Urol. 2010;57(3):488-496.

16. Oelke M, Anderson P, Wood R, Holm-Larsen T. Nocturia is often inadequately assessed, diagnosed and treated by physicians: results of an observational, real-life practice database containing 8659 European and US-American patients. Int $J$ Clin Pract. 2016;70(11):940-949.

17. Chen CY, Hsu CC, Pei YC, Yu CC, Chen YS, Chen CL. Nocturia is an independent predictor of severe obstructive sleep apnea in patients with ischemic stroke. J Neurol. 2011;258(2):189-194.

18. Romero E, Krakow B, Haynes P, Ulibarri V. Nocturia and snoring: predictive symptoms for obstructive sleep apnea. Sleep Breath. 2010;14(4):337-343.

19. Yamamoto U, Nishizaka M, Yoshimura C, et al. Prevalence of sleep disordered breathing among patients with nocturia at a urology clinic. Intern Med. 2016;55(8):901-905.

20. Bliwise DL, Holm-Larsen T, Goble S. Increases in duration of first uninterrupted sleep period are associated with improvements in PSQI-measured sleep quality. Sleep Med. 2014;15(10):1276-1278.

21. Miyauchi Y, Okazoe H, Okujyo M, et al. Effect of the continuous positive airway pressure on the nocturnal urine volume or night-time frequency in patients with obstructive sleep apnea syndrome. Urology. 2015;85(2):333-336.

22. Wang T, Huang W, Zong H, Zhang Y. The efficacy of continuous positive airway pressure therapy on nocturia in patients with obstructive sleep apnea: a systematic review and meta-analysis. Int Neurourol J. 2015;19(3):178-184.

How to cite this article: Vrooman OPJ, van Balken MR, van Koeveringe GA, et al. The effect of continuous positive airway pressure on nocturia in patients with obstructive sleep apnea syndrome. Neurourology and Urodynamics. 2020;39: 1124-1128. https://doi.org/10.1002/nau.24329 